\title{
Effect of Coarse-grain and Low-grade Iron Ores on Sinter Properties
}

\author{
Zhixin XIAO, ${ }^{1,2,3) *}$ Lingkun $\mathrm{CHEN},{ }^{2)}$ Yindong $\mathrm{YANG}^{3)}{ }^{3)}$ Xiangcai $\mathrm{LI}^{4)}$ and Mansoor BARATI ${ }^{3)}$
}

1) The State Key Laboratory of Refractories and Metallurgy, Wuhan University of Science and Technology, Wuhan, 430081

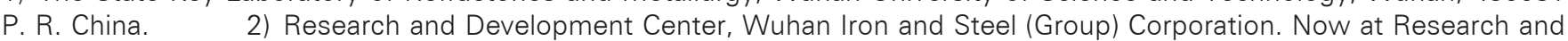
Development Center, Wuhan Iron and Steel Co., Ltd., Wuhan, 430080 P. R. China.

3) Department of Materials Science and Engineering, University of Toronto, Toronto, ON M5S 3E4 Canada.

4) Ironmaking plant, Wuhan Iron and Steel (Group) Corporation. Now at Ironmaking Plant, Wuhan Iron and Steel Co., Ltd., Wuhan, 430083 P. R. China.

(Received on November 24, 2016; accepted on February 13, 2017; J-STAGE Advance published date: April 5, 2017)

\begin{abstract}
In sintering of iron ore, small particles act as a binder that joins larger particles through diffusion and melting. In order to understand the effect of gangue and structure of coarse ore on sinter properties, melt formation in three coarse-grain, low-grade iron ores was investigated. The melt fractions at the sintering temperature were estimated using the phase diagrams and melt fluidity was quantified by testing ore compacts in an infrared furnace. The result indicates that $\mathrm{SiO}_{2}$ can significantly increase the quantity and fluidity of melt during sintering, whereas the effects of $\mathrm{Al}_{2} \mathrm{O}_{3}$ and $\mathrm{MgO}$ are small. Excessive quantity and fluidity of liquid phase result in merging of micro pores, leaving large pores behind. The impact of blending three ores with a base ore on sinter structure were tested in a mini-sinter pot. The result shows that bonding and pore structure of sinter are dominantly affected by the melt behavior and pore structure of the coarse ore. Relationships between the fluidity index of sinter feed and product properties were explored, showing meaningful and predictable trends. It was demonstrated that fluidity index can be used as parameter to link sinter mix composition and sintering conditions to the properties of the produced sinter.
\end{abstract}

KEY WORDS: gangue; ore structure; sintering; melt behavior; sinter properties; reducibility.

\section{Introduction}

The utilization of coarse-grain, low-grade iron ores which are often available at lower price compared to high quality ores is of interest to Chinese steelmakers to reduce their raw materials cost. However, the adverse effects associated with the use of these ores including high gangue content and low sinter ability have limited their consumption. Some reports have indicated that with proper sintering conditions including the time and temperature of sintering, as well as the sinter mix basicity, such negative effects can be overcome. ${ }^{1-4)}$

The small particles of iron ore blend more readily and are easier to adhere to flux and coke particles during mixing and granulating process. ${ }^{5-7)}$ Consequently, they are heated more quickly than the larger particles during sintering, both due to their smaller size and proximity to coke particles, and are also more likely to form liquid phases due to their improved fluxing. ${ }^{8-10)}$ Umadevi et al. ${ }^{11)}$ have shown that the majority of $-2.5 \mathrm{~mm}$ particles in a sinter feed will melt in the process. Meanwhile, most of the large particles that are often only partially wetted by the liquid phase play a vital role in the sinter quality, by providing a porous sinter that maintains the permeability of sinter bed. Generally, smaller

* Corresponding author: E-mail: 754808816@qq.com

DOI: http://dx.doi.org/10.2355/isijinternational.ISIJINT-2016-688 particles bond through a liquid slag whereas bonding between coarser particles is dominantly by diffusion. ${ }^{6,12,13)}$ It is therefore important to maintain an optimum size distribution and sinter mix composition for a balance of strong bonding and appropriate sinter permeability. ${ }^{14-16)}$

In this paper, the relationship between the gangue content and amount and fluidity of liquid phase formed during sintering of three coarse-grained, low-grade ores is discussed.

\section{Experimental Procedures}

\subsection{Materials}

The raw materials were collected from the stock yards of sinter plant in (Wuhan Iron and Steel Co., Ltd.). The chemical composition of four iron ores, together with the sinter additives are presented in Table 1. Table 2 shows the particle size distribution of the ores. Ores A, B and C are hematite type and considered as coarse-grain and lowgrade, compared to the typical blended ore used as the sinter mix. The blended ore is a mixture of several ore grades and is used in the present study as the reference material. As seen in Table 1, ores A-C contain a considerably higher gangue; ore $\mathrm{A}$ has the highest $\mathrm{SiO}_{2}$, ores $\mathrm{B}$ and $\mathrm{C}$ contain $3.8 \% \mathrm{Al}_{2} \mathrm{O}_{3}$, and ore $\mathrm{C}$ has the highest $\mathrm{MgO}$ among the four ores, at $1.22 \%$. 


\subsection{Assimilation Characteristics and Melt Fluidity}

2.2.1. Materials Characteristic and Preparation

Bergstrand et al. ${ }^{17)}$ have reported that the liquid phase of sinter is primarily formed by the $-0.5 \mathrm{~mm}$ particles. Other researchers ${ }^{12,13,18)}$ have carried out basic sintering experiments using grinded ores of $-0.125 \mathrm{~mm}$. In order to be able to compare the results, the ores and lime used in the assimilation and melt fluidity tests were also grinded to $-0.125 \mathrm{~mm}$ in a vibration mill.

According to literature, ${ }^{4,19,20)} \mathrm{CaO} / \mathrm{SiO}_{2}$ greater than 1.8 in the sinter feed promotes formation of calcium ferrite which is beneficial for sinter strength. In order to separate the effect of particle size and composition on the melt properties, the dry final feed, with composition shown in Table $\mathbf{3}$, was screened to various size fractions, and the $\mathrm{CaO} / \mathrm{SiO}_{2}$ ratio was measured for each batch. Figure 1 provides the results indicating that the basicity is rather uneven across the range of particle sizes. The average basicity of sintered dry final feed was found to be close to the starting material (1.76 after sintering, versus 1.8). The highest and lowest

Table 1. Chemical composition of the iron ores (wt- $\%$ ) used in the present study.

\begin{tabular}{crrrrrrr}
\hline Iron ore & $\mathrm{TFe}$ & $\mathrm{FeO}$ & $\mathrm{SiO}_{2}$ & $\mathrm{Al}_{2} \mathrm{O}_{3}$ & $\mathrm{MgO}$ & $\mathrm{CaO}$ & $\mathrm{LOI}$ \\
\hline $\mathrm{A}$ & 53.51 & 0.90 & 15.65 & 1.32 & 0.29 & 0.93 & 3.4 \\
$\mathrm{~B}$ & 55.29 & 1.13 & 10.41 & 3.88 & 0.12 & 0.42 & 4.6 \\
$\mathrm{C}$ & 47.32 & 0.97 & 8.93 & 3.76 & 1.22 & 1.03 & 2.4 \\
Blended ore & 62.08 & 1.66 & 5.83 & 1.74 & 0.25 & 0.17 & 3.1 \\
Lime & 0.22 & & 3.01 & 0.31 & 0.74 & 82.53 & 0.5 \\
Limestone & 1.46 & & 2.48 & 0.21 & 3.88 & 50.36 & 48.6 \\
Dolomite & 2.34 & & 1.14 & 0.11 & 19.54 & 32.29 & 46.7 \\
Coke breeze & 2.01 & & 5.68 & 3.41 & 0.21 & 0.17 & 12.3 \\
\hline
\end{tabular}

Table 2. Particle size distribution of iron ores (wt- $\%$ ).

\begin{tabular}{crrrrrr}
\hline \multirow{2}{*}{ Iron ore } & \multicolumn{6}{c}{ Size $(\mathrm{mm})$} \\
\cline { 2 - 7 } & +5 & $3.5-5$ & $2-3.5$ & $1-2$ & $0.5-1$ & -0.5 \\
\hline A & 32.6 & 25.1 & 16.1 & 14.0 & 5.0 & 7.2 \\
B & 50.5 & 13.8 & 7.7 & 7.2 & 9.2 & 11.6 \\
C & 57.9 & 20.6 & 10.7 & 6.4 & 2.5 & 1.9 \\
Blended ore & 21.9 & 18.7 & 18.7 & 14.4 & 7.0 & 19.4 \\
\hline
\end{tabular}

Table 3. Composition of the dry final feed.

\begin{tabular}{|c|c|c|c|c|c|c|}
\hline \multicolumn{6}{|c|}{ Constituents (wt-\%) } & \multirow{2}{*}{$\begin{array}{c}\mathrm{CaO} / \mathrm{SiO}_{2} \\
\text { (sinter) }\end{array}$} \\
\hline $\begin{array}{l}\text { Blend } \\
\text { ore }\end{array}$ & $\begin{array}{c}\text { Return } \\
\text { sinter }\end{array}$ & Lime & Limestone & Dolomite & Coke & \\
\hline 55 & 30 & 2.1 & 6.5 & 2.5 & 3.90 & 1.76 \\
\hline
\end{tabular}

basicity values were 2.53 and 1.5 for the $1.0-2.0 \mathrm{~mm}$ and $+5.0 \mathrm{~mm}$ fractions, respectively. Considering these findings, the range of basicity covered in the fluidity was varied between 1.0 and 3.0.

\subsubsection{Sintering Regime}

The formation of calcium ferrite in sinter is known to improve its properties significantly. ${ }^{13,21)}$ Literature $^{22-24)}$ also indicates that the proper sintering conditions for calcium ferrite formation are treatment of up to 3 minutes at $1200-1300^{\circ} \mathrm{C}$.

Figure 2 shows the temperature profiles in the upper $(100 \mathrm{~mm})$, middle $(300 \mathrm{~mm})$ and lower $(500 \mathrm{~mm})$ layers of the bed in a sinter pot with $\varnothing 200 \mathrm{~mm}$ and $700 \mathrm{~mm}$ height. From top to bottom, the maximum measured temperatures are $1265^{\circ} \mathrm{C}, 1340^{\circ} \mathrm{C}$, and $1400^{\circ} \mathrm{C}$, respectively, with corresponding sintering time above $1250^{\circ} \mathrm{C}$ of $0.8,2.1$, and 2.9 minutes. In a series of mini-pot sintering tests described later, the temperature profile of the middle layer of the large

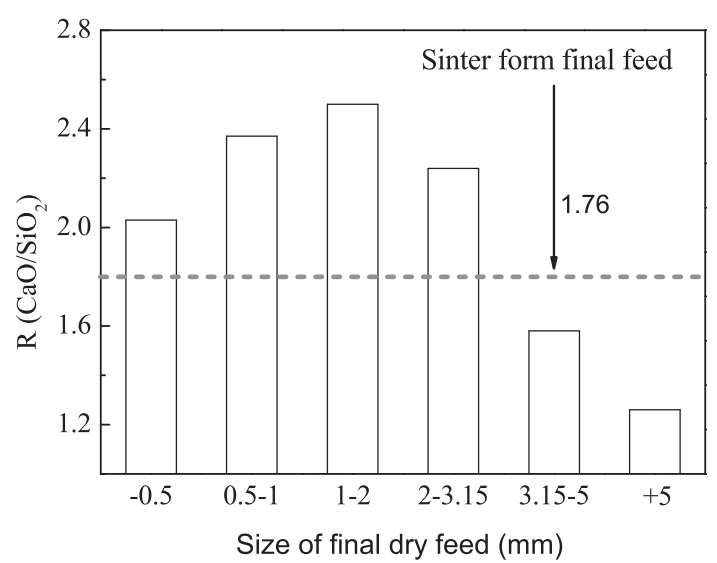

Fig. 1. Basicity distribution in different size fractions of the dry final feed.

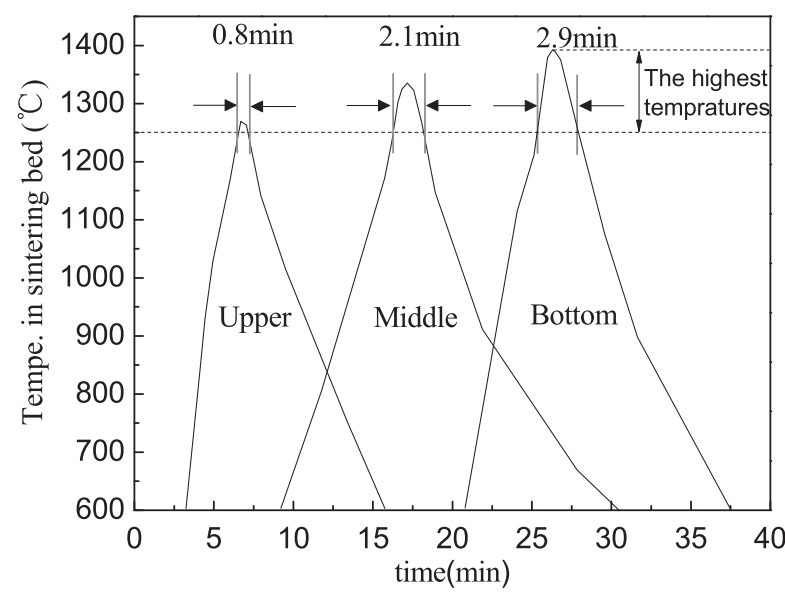

Fig. 2. Temperature profiles at different positions of the sintering bed in a pot.

Table 4. The test procedures in mini-pot sintering.

\begin{tabular}{ccccccccc}
\hline Stage & \multicolumn{2}{c}{ Rising period of temperature } & \multicolumn{2}{c}{ Soaking period } & \multicolumn{2}{c}{ Cooling period } \\
Atmosphere & \multicolumn{3}{c}{$\mathrm{N}_{2}(2.0 \mathrm{~L} / \mathrm{min})$} & \multicolumn{2}{c}{ Air $(2.0 \mathrm{~L} / \mathrm{min})$} \\
\hline Temp. $\left({ }^{\circ} \mathrm{C}\right)$ & $0 \rightarrow 600$ & $\rightarrow 1000$ & $\rightarrow 1200$ & $\rightarrow \mathrm{Max}$ & $\mathrm{Max}$ & $\rightarrow 100$ & $\rightarrow 1000$ & $\rightarrow 400$ \\
Time (min) & 5 & 2.5 & 1.5 & 1.5 & $0-3.0$ & 2.0 & 1.5 & 5 \\
\hline
\end{tabular}


pot was reproduced by applying the heating regime shown in Table 4.

\subsubsection{Assimilation Tests}

The assimilation of iron ores with lime was studied at $1300^{\circ} \mathrm{C}$. Disks of iron ore (6 mm dia., $5 \mathrm{~mm}$ height) were prepared by compacting $-0.125 \mathrm{~mm}$ particles in a die under a $10 \mathrm{MPa}$ load using a hydraulic press. The same procedure was employed to produce disks of lime with $20 \mathrm{~mm}$ dia. and $5 \mathrm{~mm}$ height. The iron ore disk was centered on the lime disk, the two were then placed in an infrared furnace, and heated according to the program presented in Table 3. The quantities of lime reacted with the four types of ores were then quantified.

\subsubsection{Melt Fluidity Tests}

Iron ores of $-0.125 \mathrm{~mm}$ were first blended with appropriate amounts of lime to reach the desired basicity. Then, the mixture was pressed into compacts of $6 \mathrm{~mm}$ dia., $5 \mathrm{~mm}$ height, and heated in the infrared furnace following the procedures of Table 3 .

The degree of spreading of compacts during sintering was used to evaluate melt fluidity. In sintering process, the primary liquid will assimilate the large particles, thus the spreading and interactions are critical to the bonding condition along the melt-particle interface. The initial $\left(\mathrm{A}_{0}\right)$ and spread $\left(A_{1}\right)$ areas were measured as seen in Fig. 3, and used in Eq. (1) to determine the fluidity index, F. Using this technique, the effects of sintering time and temperature, as well as the mixture basicity on melt fluidity were established and cast into empirical correlations. Further, the structure of the produced sinter was investigated using optical microscope.

$$
\mathrm{F}=\frac{\mathrm{A}_{1}-\mathrm{A}_{0}}{\mathrm{~A}_{0}}
$$

\subsection{Mini-pot Sintering}

In order to investigate the effect of the three ores on sintering behavior and sinter structure, tests were carried out in a mini-pot. First, three mixtures were prepared by adding ores $\mathrm{A}, \mathrm{B}$ and $\mathrm{C}$ to the blended ore in a ratio of $15: 85$. The sinter feed was produced by blending these ore mixtures with sinter return $(30 \%)$, coke $(3.9 \%)$ and appropriate amounts of lime, limestone and dolomite to adjust the calculated basicity to 1.8 . Then, the material was fed to a drum mixer (dia. $300 \mathrm{~mm}$ ) and blended for $3.0 \mathrm{~min}$ while $\sim 6.3 \mathrm{wt} \%$ of atomized water was added.

The mini-pot consisted of a corundum-tube $(\varnothing=25 \mathrm{~mm}$, height $=30 \mathrm{~mm}$ ) that was filled with $15 \mathrm{~g}$ final feed, and was expected to duplicate the sintering conditions in the middle layer of the larger pot, by following the heating procedures of Table 3. The maximum temperature in these tests was $1300^{\circ} \mathrm{C}$ with a dwell time of $1.0 \mathrm{~min}$. Air was purged from the bottom of pot during sintering. After cooling, the specimen was sectioned and observed under optical microscope to study the structure and mineralogy of the sinter.

\subsection{Standard-pot Sintering}

In order to investigate the relationship between the fluidity index and sinter properties, the final feed was sintered in a standard sintering pot of $200 \mathrm{~mm}$ dia. and $700 \mathrm{~mm}$ height,

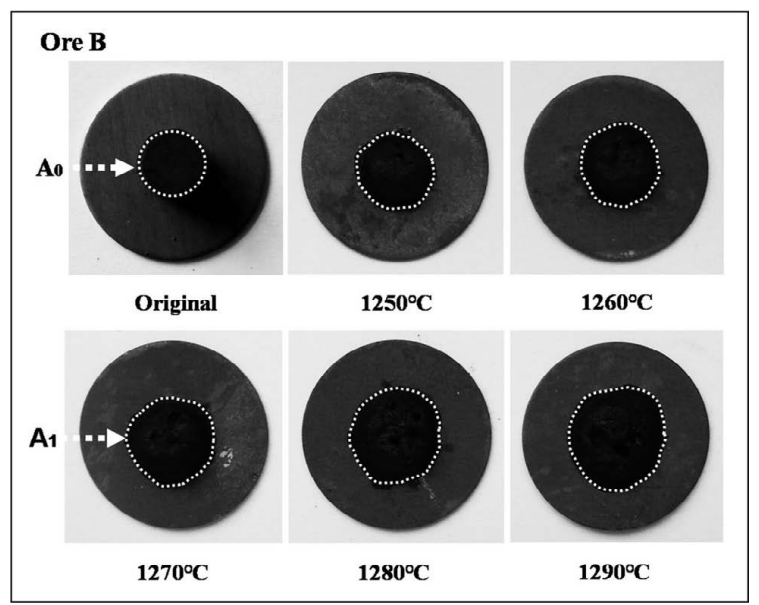

Fig. 3. Original and spread samples sintered form 1250 to $1290^{\circ} \mathrm{C}$.

Table 5. Blend composition and particle size distribution of feed in pot sintering tests.

\begin{tabular}{ccccccccc}
\hline & \multicolumn{3}{c}{ Mixture } & \multicolumn{5}{c}{ Final feed } \\
\cline { 2 - 9 } Tests & \multicolumn{3}{c}{ Composition (wt.\%) } & Moisture & \multicolumn{2}{c}{ Size Distribution/(wt.\%) } \\
\cline { 2 - 9 } & $\begin{array}{c}\text { Blended } \\
\text { ore }\end{array}$ & $\begin{array}{c}\text { Ore } \\
\text { A }\end{array}$ & $\begin{array}{c}\text { Ore } \\
\text { B }\end{array}$ & $\begin{array}{c}\text { Ore } \\
\text { C }\end{array}$ & (wt. $\%)$ & $\begin{array}{c}-2.0 \\
\text { mm }\end{array}$ & $\begin{array}{c}2.0-3.15 \\
\text { mm }\end{array}$ & $\begin{array}{c}+3.15 \\
\text { mm }\end{array}$ \\
\hline S1 & 85 & 5 & 10 & & 6.22 & 38.30 & 10.30 & 51.40 \\
S2 & 85 & 10 & 5 & & 6.07 & 39.66 & 10.47 & 49.87 \\
S3 & 85 & 15 & & & 6.34 & 38.90 & 13.06 & 48.04 \\
S4 & 85 & & 5 & 10 & 6.42 & 34.74 & 12.32 & 52.94 \\
S5 & 85 & & 10 & 5 & 6.01 & 36.83 & 11.36 & 51.81 \\
S6 & 85 & & 15 & & 6.17 & 40.21 & 9.46 & 50.33 \\
S7 & 85 & 10 & & 5 & 6.11 & 37.88 & 13.86 & 48.26 \\
S8 & 85 & 5 & & 10 & 6.35 & 36.33 & 13.21 & 50.46 \\
S9 & 85 & & & 15 & 6.47 & 34.07 & 12.80 & 53.13 \\
S10 & 85 & 5 & 5 & 5 & 6.44 & 38.89 & 10.67 & 50.44 \\
S & 100 & & & & 6.32 & 38.16 & 13.97 & 47.87 \\
\hline
\end{tabular}

and the sinter properties were studied. As shown in Table $\mathbf{5}$, ten mixtures of blended ore $(85 \%)$ and low-grade ores $(15 \%)$ were prepared using a procedure similar to the minipot tests. For each mixture, the material was charged into the pot and ignited at $1050^{\circ} \mathrm{C}$ for $2.0 \mathrm{~min}$ while a draft of $-10 \mathrm{kPa}$ was maintained during the process. After cooling in the air, sinter quality indices such as drum strength (ISO TI), Reduction Degree (RI), Low Temperature Reduction Degradation Index (RDI), and softening properties were evaluated. In addition, the coke consumption and $\mathrm{FeO}$ content of the sinter were quantified.

\section{Results and Discussion}

\subsection{Theoretical Assessment of Melt Formation and Fluidity}

3.1.1. Effect of Gangue on Liquid Formation

Ores A, B, C, as shown in Table 1 have a relatively wide range of $\mathrm{SiO}_{2}$ from $9-16 \%$, which is a component known to significantly affect liquid phase formation in sinter. ${ }^{13,15)}$ Other components have shown different effects. 
For example, Kongoli and Yazawa ${ }^{25)}$ reported that increasing $\mathrm{Al}_{2} \mathrm{O}_{3}$ up to $7 \%$ in $\mathrm{Fe}_{2} \mathrm{O}_{3}-\mathrm{CaO}-\mathrm{SiO}_{2}-\mathrm{Al}_{2} \mathrm{O}_{3}$ results in approximately $6-8^{\circ} \mathrm{C}$ increase in liquidus temperature of slag per each $1 \%$ of alumina. For a similar ternary system of $\mathrm{Fe}_{2} \mathrm{O}_{3}-\mathrm{CaO}-\mathrm{SiO}_{2}$, the liquid region of the phase diagram was enlarged by the addition of $\mathrm{Al}_{2} \mathrm{O}_{3}$ and shrunk by the addition of $\mathrm{MgO}$ at $1300^{\circ} \mathrm{C}$. $^{26)}$

In the current study, the phase diagrams of $\mathrm{Fe}_{2} \mathrm{O}_{3}-\mathrm{CaO}-$ $\mathrm{SiO}_{2}$ system corresponding to the compositions of the three coarse-grain and low-grade ores were produced using FactSage ${ }^{\mathrm{TM}}$ 7.0, and the effect of ore gangue content on liquid phase at a temperature of $1200-1350^{\circ} \mathrm{C}$ was investigated. Because of the small and comparable concentrations of $\mathrm{FeO}$ in the three original ores, the $\mathrm{FeO}$ content in the following diagrams was fixed at $1.0 \%$.

Figures 4-7 present the liquid region in the $\mathrm{Fe}_{2} \mathrm{O}_{3}-\mathrm{CaO}-$ $\mathrm{SiO}_{2}$ with different additions of $\mathrm{Al}_{2} \mathrm{O}_{3}$ and $\mathrm{MgO}$.

Figure 4 shows that at $1300^{\circ} \mathrm{C}$ there are three liquid phase areas. Zone $\mathrm{I}$ is an isolated area with $\mathrm{Fe}_{2} \mathrm{O}_{3}$ of approximately $20 \%-35 \%$ and basicity of $0.43-0.53$. Zone II

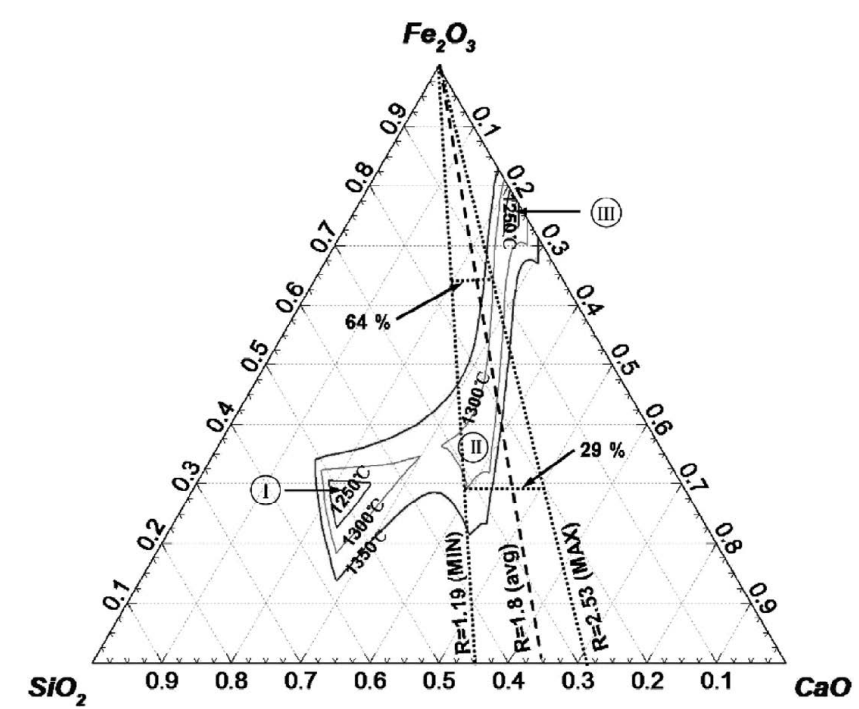

Fig. 4. Liquidus isotherms for the $\mathrm{Fe}_{2} \mathrm{O}_{3}-\mathrm{SiO}_{2}-\mathrm{CaO}$ system at $1250-1350^{\circ} \mathrm{C}(1 \mathrm{mass} \% \mathrm{FeO})$.

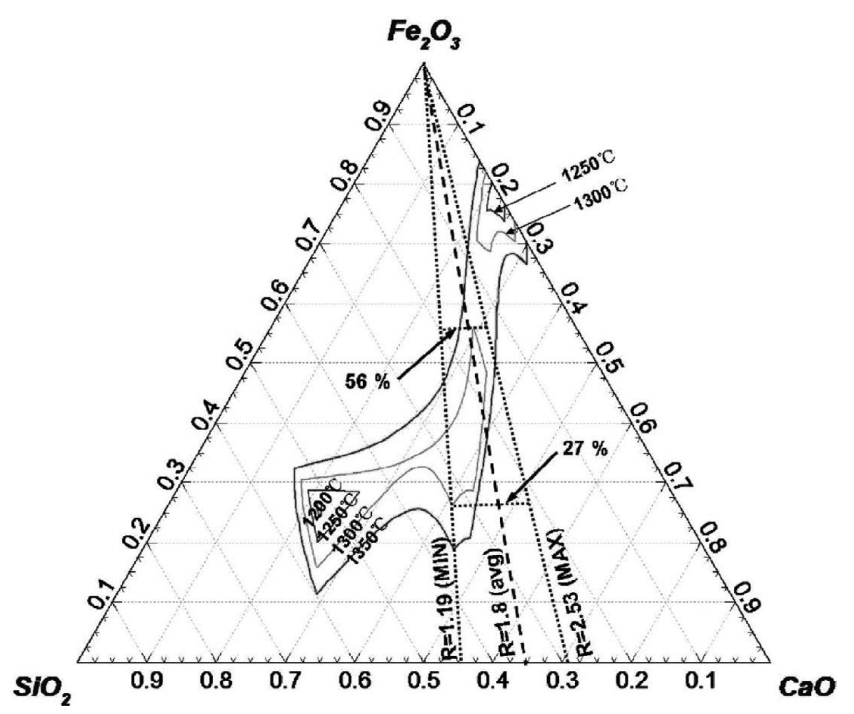

Fig. 5. Liquidus isotherms for $\mathrm{Fe}_{2} \mathrm{O}_{3}-\mathrm{SiO}_{2}-\mathrm{CaO}-1.32$ mass $\%$ $\mathrm{Al}_{2} \mathrm{O}_{3}$ at $1250-1350^{\circ} \mathrm{C}(1 \mathrm{mass} \% \mathrm{FeO})$. and III are joined to a long narrow strip with $\mathrm{Fe}_{2} \mathrm{O}_{3}$ ranging from 29 to $80 \%$, Zone II with the basicity of $\sim 1.2$ and Zone III with the basicity greater than 10 . According the basicity range in the sinter feed (1.19-2.53) that falls on or around Zone II this is where liquid composition could be during sintering. The $\mathrm{Fe}_{2} \mathrm{O}_{3}$ concentration at $1300^{\circ} \mathrm{C}$ in this zone is in the $29-64 \%$ range depending on the basicity. For the ores with lower basicity (higher $\mathrm{SiO}_{2}$ ), the liquid region is widened, covering a greater range of $\mathrm{Fe}_{2} \mathrm{O}_{3}$. This indicates that a sinter made from ore $\mathrm{A}$ would have a larger amount of liquid than $\mathrm{B}$ and $\mathrm{C}$ at $1300^{\circ} \mathrm{C}$.

Figure 5 shows the Liquidus isotherms for ore $\mathrm{A}$ with $1.32 \mathrm{Al}_{2} \mathrm{O}_{3}$. Compared to the $\mathrm{Al}_{2} \mathrm{O}_{3}$-free system (Fig. 4) at $1300^{\circ} \mathrm{C}$, addition of this small amount of alumina expands Zone II so that it is merged with Zone I, while Zone III is separated from Zone II. The liquid region in this system at the basicity of 1.19-2.53 covers a smaller $\mathrm{Fe}_{2} \mathrm{O}_{3}$ content of $27-56 \%$ at $1300^{\circ} \mathrm{C}$. Figure 6 shows the liquidus for ore $\mathrm{B}$ with $3.88 \% \mathrm{Al}_{2} \mathrm{O}_{3}$. Comparing Figs. 6 with 5 at $1300^{\circ} \mathrm{C}$, one can see a larger liquid region in the middle of diagram

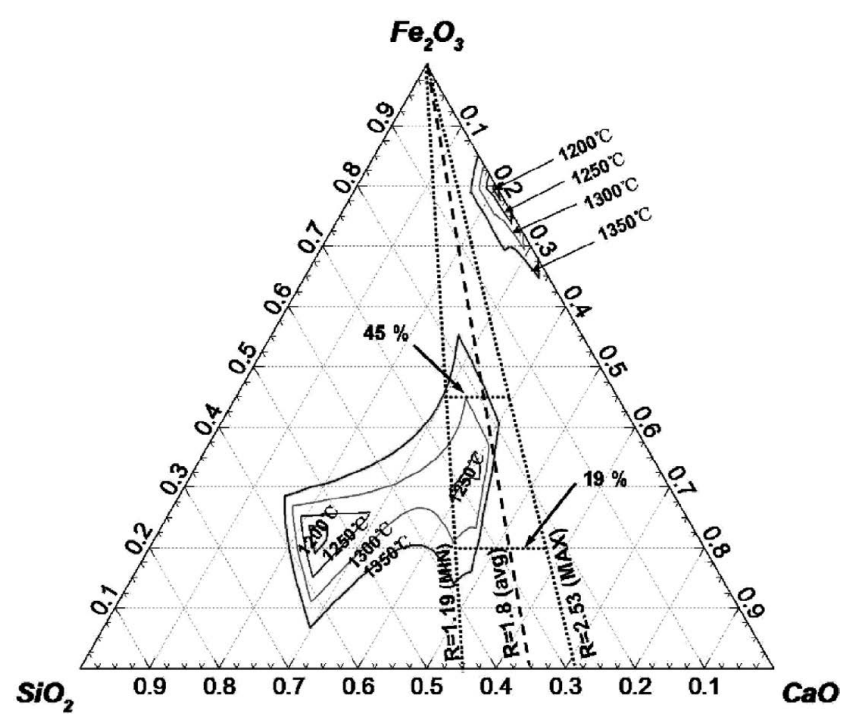

Fig. 6. Liquidus isotherms for $\mathrm{Fe}_{2} \mathrm{O}_{3}-\mathrm{SiO}_{2}-\mathrm{CaO}-3.88$ mass $\%$ $\mathrm{Al}_{2} \mathrm{O}_{3}$ at $1250-1350^{\circ} \mathrm{C}(1$ mass $\% \mathrm{FeO})$.

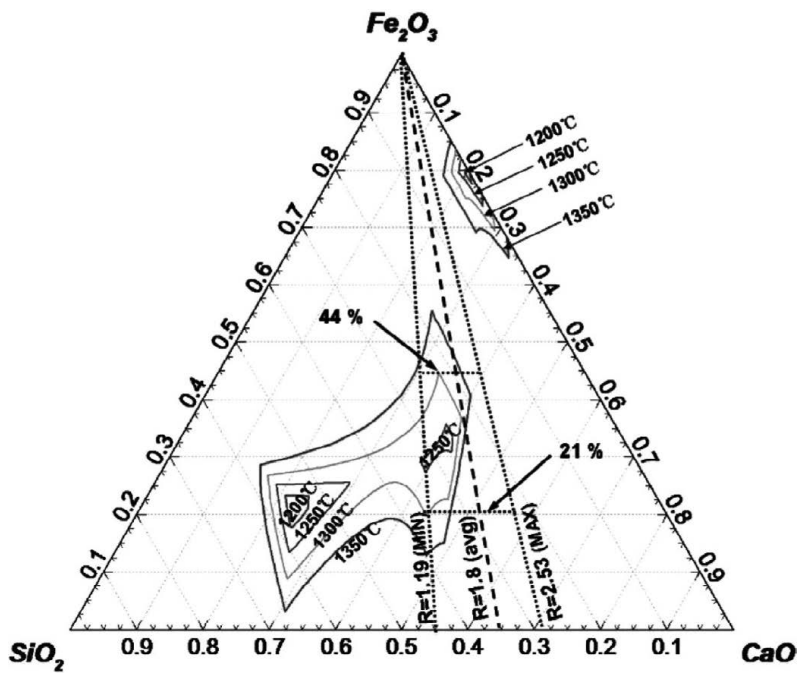

Fig. 7. Liquidus isotherms for $\mathrm{Fe}_{2} \mathrm{O}_{3}-\mathrm{SiO}_{2}-\mathrm{CaO}-3.76$ mass $\%$ $\mathrm{Al}_{2} \mathrm{O}_{3}-1.22$ mass $\% \mathrm{MgO}$ at $1250-1350^{\circ} \mathrm{C}$ (1 mass $\%$ $\mathrm{FeO})$. 
(merging of Zones I and II) and a smaller content of $\mathrm{Fe}_{2} \mathrm{O}_{3}$ in this region, 19-45\%. Figure 7 displays the liquidus isotherms for ore $\mathrm{C}$ with $3.76 \% \mathrm{Al}_{2} \mathrm{O}_{3}$ and $1.22 \% \mathrm{MgO}$. In comparison with Fig. 6 at $1300^{\circ} \mathrm{C}$, Zone I has expanded and Zone II has slightly shrunk, with the percent of $\mathrm{Fe}_{2} \mathrm{O}_{3}$ in liquid region being $21-44 \%$.

The above results show that the liquid formation is greater for ore $\mathrm{A}$ and is suppressed when ores $\mathrm{B}$ and $\mathrm{C}$ are used. The effects of $\mathrm{SiO}_{2}, \mathrm{Al}_{2} \mathrm{O}_{3}$, and $\mathrm{MgO}$ on melt formation are consistent with earlier reports and will be discussed in the following sections based on sintering tests.

\subsubsection{Effect of Gangue on Melt Fluidity}

The viscosity of melt formed during sintering of the three ores with basicity of 1.8 at $1250^{\circ} \mathrm{C}$ was calculated using FactSage $^{\text {TM }}$ 7.0. The results, presented in Fig. 8, indicate significantly lower viscosity for melt $\mathrm{A}$, and comparable values for $\mathrm{B}$ and $\mathrm{C}$. The blended ore, currently being used at WISCO would have a melt with the highest viscosity. These results confirm the critical effect of $\mathrm{SiO}_{2}$ on melt fluidity, in addition to its known effect on melt quantity.

\subsection{Effect of Blend Composition and Sintering Regime on the Melt Fluidity}

\subsubsection{Effect of Gangue on Assimilation}

Figure 9 presents the extent of assimilation with lime for the four kinds of ores at $1300^{\circ} \mathrm{C}$. Ore $\mathrm{A}$ has the highest assimilation, presumably because of its high $\mathrm{SiO}_{2}$ content. Ores $\mathrm{B}$ and $\mathrm{C}$ exhibit lower assimilation than $\mathrm{A}$, and slightly better than the blended ore, which can be explained by their $\mathrm{SiO}_{2}$ and $\mathrm{Al}_{2} \mathrm{O}_{3}$ contents. Higher $\mathrm{MgO}$ in $\mathrm{C}$ may have been

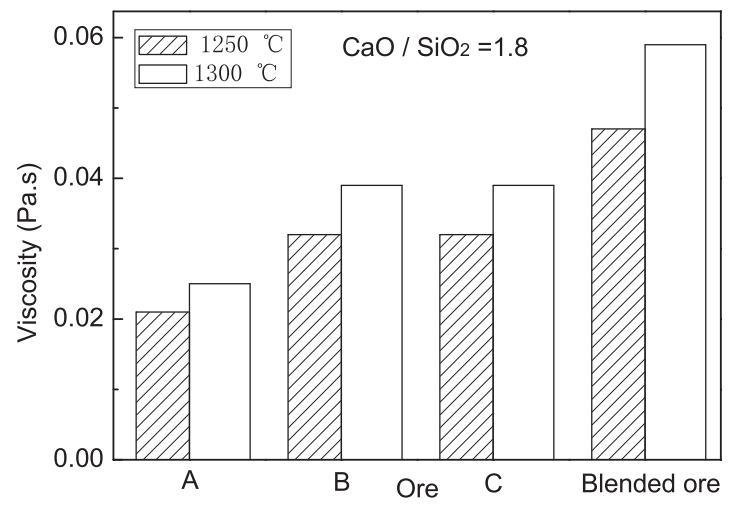

Fig. 8. Calculated viscosity of melt formed from different ores.

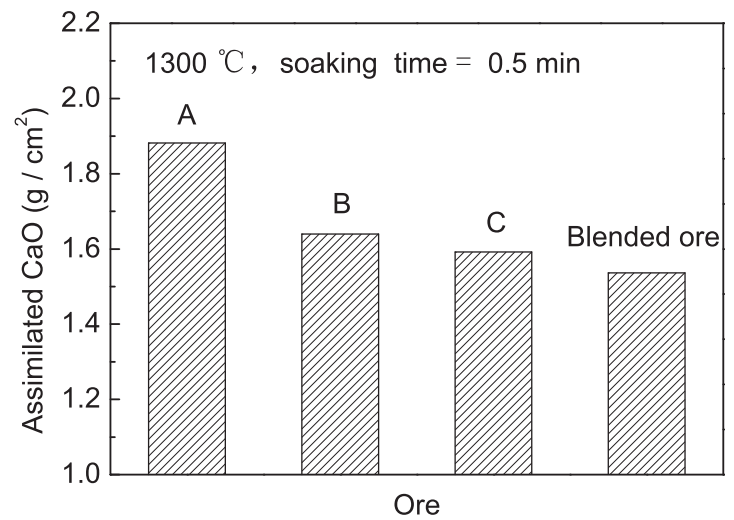

Fig. 9. Amount of assimilated $\mathrm{CaO}$ with different ores at $1300^{\circ} \mathrm{C}$. the reason for greater assimilation in $\mathrm{C}$ than $\mathrm{B}$. These results are also consistent with the variation of liquid region (Zone II) discussed above.

\subsubsection{Effect of Basicity on Fluidity Index of Sinter Melt}

Figure 10 shows the relationship between fluidity index of melt and basicity for the three coarse ores and the ore blend. For each material, samples were prepared with a range of basicity, and sintered at $1260^{\circ} \mathrm{C}$ for $2.0 \mathrm{~min}$. The empirical correlation was established between the fluidity indexes $(F)$ and basicity $(R)$ by regression analysis, with the results provided in Eqs. (2)-(5). The correlations are strong, showing increased melt fluidity with basicity, and at the same time, there are noticeable differences between different ores, ore A showing the highest fluidity, followed by B, C, and finally the blended ore. The constants and coefficients in these correlations have different sigs for each ore which is a result of regression which yields constants that would produce the best fit between the experimental data and the curve.

$$
\begin{array}{r}
F_{\mathrm{A}}(R)=0.046+0.304 R+0.133 R^{2} \\
F_{\mathrm{B}}(R)=2.681-2.785 R+0.768 R^{2} \\
F_{\mathrm{C}}(R)=-1.081+0.683 R \ldots \ldots \ldots \\
F_{\text {blend }}(R)=-5.687+4.101 R-643 R^{2}
\end{array}
$$

\subsubsection{Effect of Temperature on the Fluidity Index of Sin- ter Melt}

Figure 11 shows that the fluidity index of samples increases with the increase of temperature. The samples with $\mathrm{CaO} / \mathrm{SiO}_{2}$ of 2.6 were heated form 1220 to $1300^{\circ} \mathrm{C}$ in interval of $10^{\circ} \mathrm{C}$ for $2.0 \mathrm{~min}$. Comparing the results, the trend of fluidity is as following, A has the highest index while $\mathrm{B}, \mathrm{C}$, and blended ore show comparable values. The regression equations of fluidity index $(F)$ as a function of temperature $(T)$ are presented in Eqs. (6)-(9).

$$
F_{\mathrm{A}}(T)=-244.060+0.360 T-1.312 \times 10^{-4} T^{2}
$$

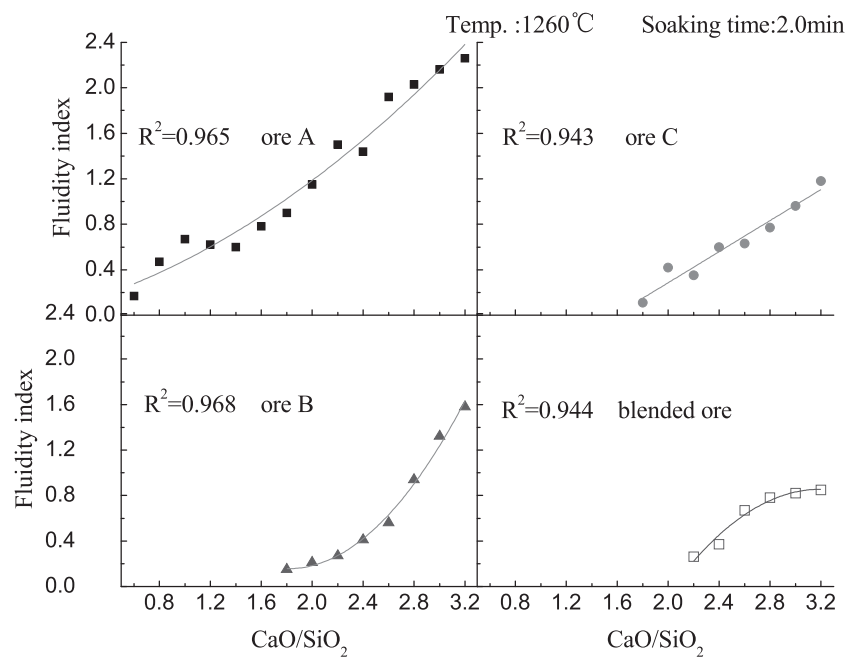

Fig. 10. Relationship between fluidity index of sintering melt and $\mathrm{CaO} / \mathrm{SiO}_{2}$. 


$$
\begin{array}{r}
F_{\mathrm{B}}(T)=-565.126-0.912 T-3.679 \times 10^{-4} T^{2} \\
F_{\mathrm{C}}(T)=-272.109-0.445 T-1.821 \times 10^{-4} T^{2} \\
F_{\text {blend }}(T)=-36.521-0.029 T \ldots \ldots \ldots \ldots \ldots \ldots
\end{array}
$$

\subsubsection{Effect of Soaking Time on Fluidity Index of Sinter-} ing Melt

Ore samples with $\mathrm{CaO} / \mathrm{SiO}_{2}$ of 2.6 were sintered at $1260^{\circ} \mathrm{C}$ with 1.0 to $3.0 \mathrm{~min}$ holding time at this temperature. The results are shown in Fig. 12 and the regression equations are presented below. Similar to the effect of temperature, Ore A has the highest fluidity indexes, while B, $\mathrm{C}$, and blended ore show comparable values. This follows a trend consistent with the $\mathrm{SiO}_{2}$ content of the ores.

$$
\begin{array}{r}
F_{\mathrm{A}}(t)=0.682+0.731 t-0.943 t^{2} \\
F_{\mathrm{B}}(t)=0.040+0.274 t \ldots \ldots \ldots
\end{array}
$$

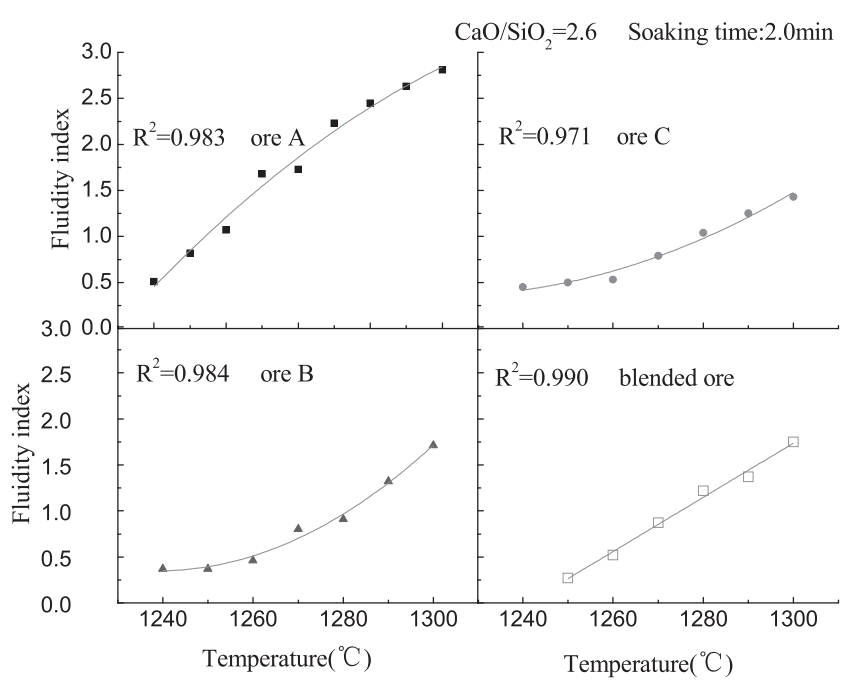

Fig. 11. Relationship between fluidity index of sintering melt and temperature.

$$
\begin{array}{r}
F_{\mathrm{C}}(t)=0.162+0.198 t \ldots \ldots \ldots \ldots \\
F_{\text {blend }}(t)=-0.028+0.540 t-0.0886 t^{2}
\end{array}
$$

The above results indicate that the quantity and behavior of melt in sintering depends on gangue content, particularly $\mathrm{SiO}_{2}$, as well as basicity, temperature and soaking time. According to the Eqs. (2)-(5) and (6)-(9) and (10)-(13), it can be deduced that the quality of reactant $(\mathrm{CaO})$ and temperature are the two main factors affecting the rates of formation and spreading of liquid. It is also evident that the soaking time affects the rates but not the same extent.

\subsection{Effect of Melt Fluidity and Amount on Sinter Structure and Mineral Phases}

Figure 13 shows the cross-section of sinters made from the four ores at $1260^{\circ} \mathrm{C}$ for $1.0 \mathrm{~min}$. The basicity for all sinter feeds was adjusted to 1.8 . It can be seen that a large pore of $2.7 \mathrm{~mm}$ and several pores $<1 \mathrm{~mm}$ are formed in sinter $\mathrm{A}$. ores $\mathrm{B}$ and $\mathrm{C}$ contain a larger number of pores

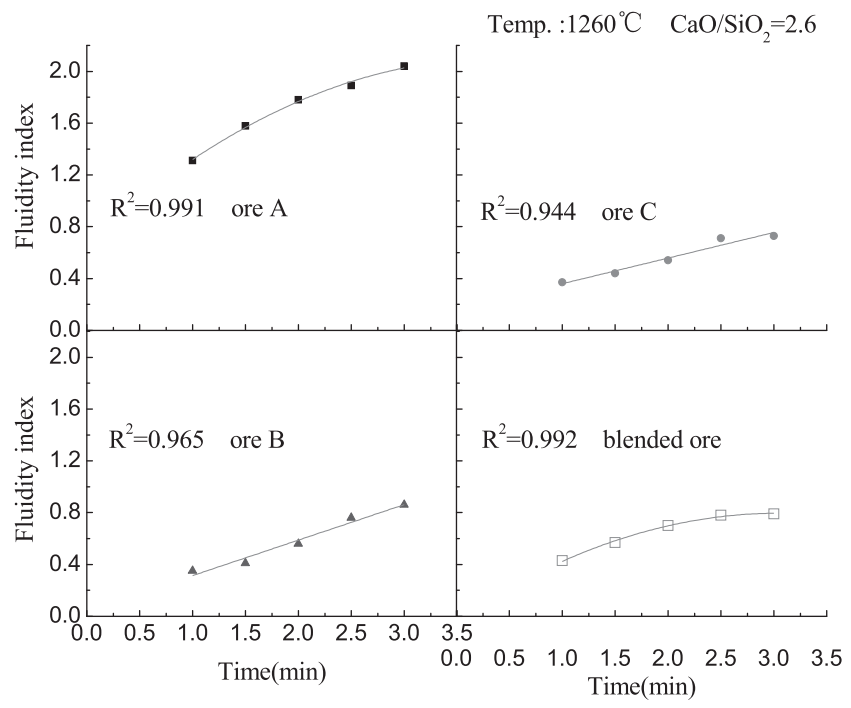

Fig. 12. Relationship between fluidity index of sintering melt and soaking time at $1260^{\circ} \mathrm{C}$

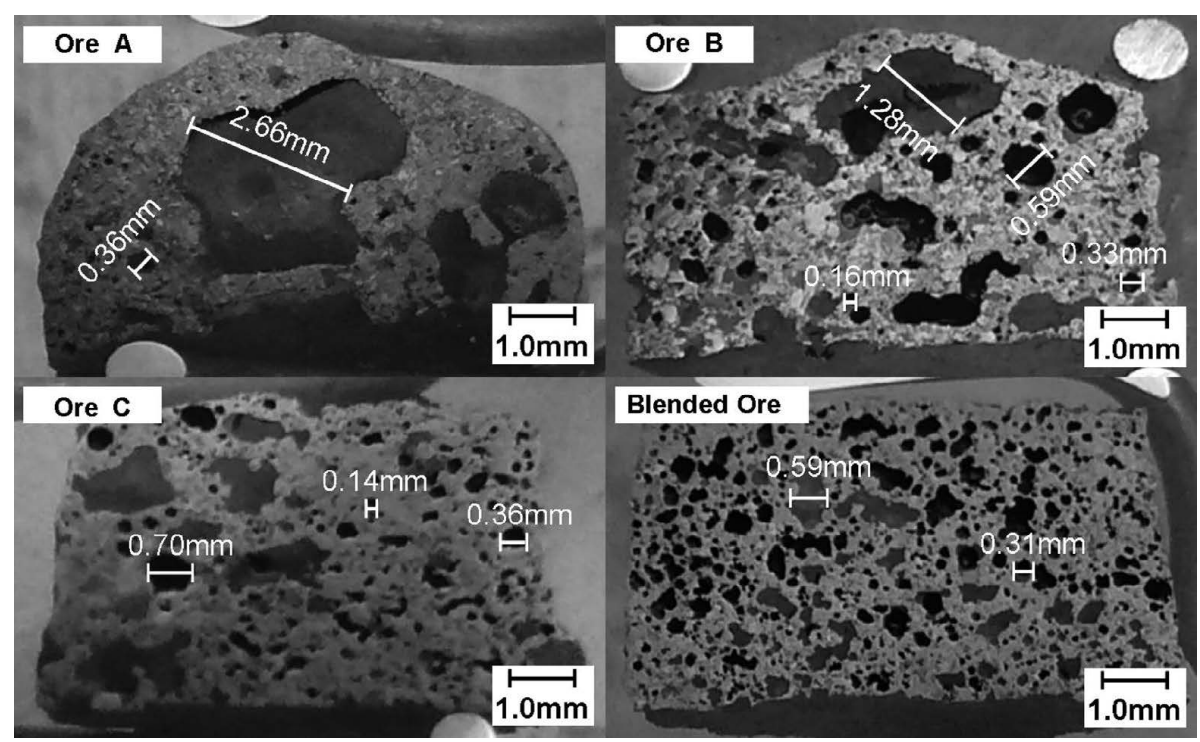

Fig. 13. Cross section of fluidity samples sintered at $1260^{\circ} \mathrm{C}$ for $1.0 \mathrm{~min}\left(\mathrm{CaO} / \mathrm{SiO}_{2}=1.8\right)$. 

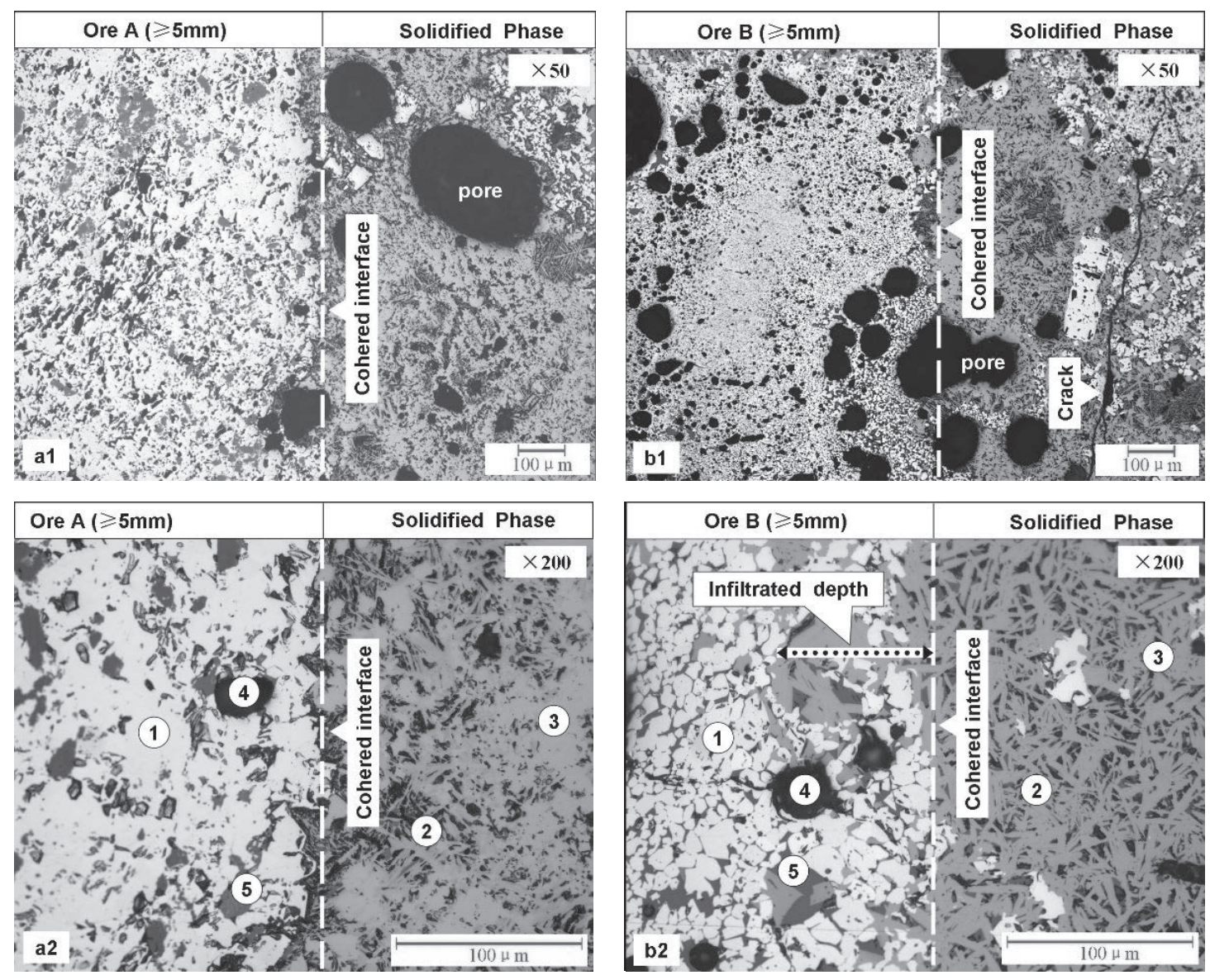

(a) $15 \%$ ore $\mathrm{A}+85 \%$ base ore

(b) $15 \%$ ore $\mathrm{B}+85 \%$ base ore
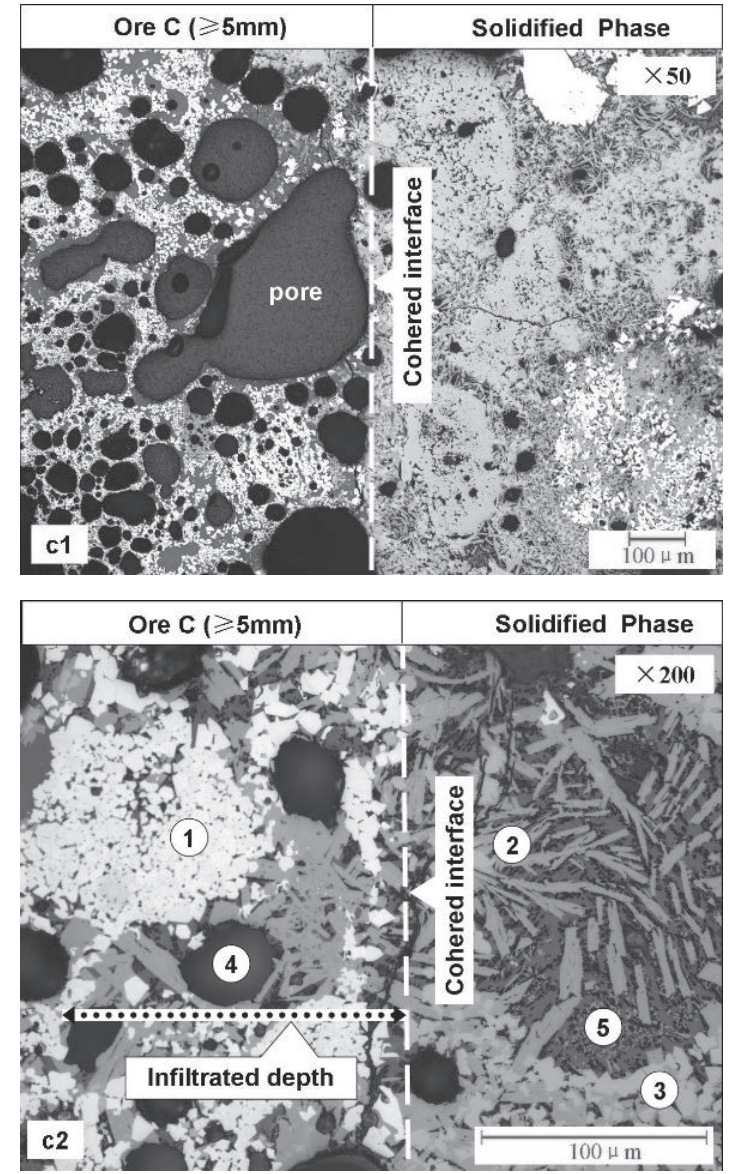

(c) $15 \%$ ore $\mathrm{C}+85 \%$ base ore

Fig. 14. Microstructures of sample sintered at $1300^{\circ} \mathrm{C}$ for $1.0 \mathrm{~min}$ in the mini pot. $\left(\mathrm{CaO} / \mathrm{SiO}_{2}=1.8\right) 1$. Hematite, 2. Calcium ferrite, 3. Magnetite, 4. Pore, 5. Silicate. 
in the range of $0.5-1.0 \mathrm{~mm}$. Blended ore has the highest number of visible pores, and they look more uniform in size with majority in the $0.5-1.0 \mathrm{~mm}$ range. These results indicate that excessive melt fluidity and content, as expected for ore A, result in formation of larger pores at the expense of merging smaller ones. Conversely, when the melt does not have the sufficient quantity and fluidity, the tendency is towards formation of a large number of small pores. Both these extreme cases produce a sinter of low quality.

Figure 14 shows the microstructure of sinters produced in the mini pot at $1300^{\circ} \mathrm{C}$ for $1.0 \mathrm{~min}$ from a mixture of one of the coarse ores $(\mathrm{A}-\mathrm{C})$ and the blended ore. The wetting of large particles $(+5.0 \mathrm{~mm})$ with melt and bonding of them is of interest to investigate the effect of coarse ore on sinter structure. Figure 14(a1) exhibits formation of a few pores along the melt-particle interface. This is due to the excessive quantity and fluidity of the melt, i.e. the bonding phase, which leads to merging of pores and draining of the melt from these particles, leaving large pores near them. Figure 14(a2) confirms that the $+5.0 \mathrm{~mm}$ particles of ore A are difficult to be wetted by the melt. Figure 14(b1) corresponding to ore B shows a structure with a large number of pores and cracks along the interface. The reason for this is believed to be that the melt infiltration between particles has been suppressed due to the inadequate melt fluidity of ore B. Figure 14(b2) shows that the $+5.0 \mathrm{~mm}$ particles of ore $\mathrm{B}$ are thinly coated by the melt and a melt-infiltrated layer with little porosity has formed at edge of large particles. As seen in Fig. 14(c1), there are less pores in the solidified phase along the interface because of the easily percolated structure and proper melt fluidity of ore C. Figure 14(c2) shows that the $+5.0 \mathrm{~mm}$ particles of ore $\mathrm{C}$ are more easily wetted by melt than ore B due to the lower density (higher porosity), so the melt-infiltrated layer is thicker. Further, the formation of SFCA (Silico-ferrites of Calcium and Aluminum) was confirmed using SEM-EDS, as shown in Fig. 15. In general, the sinter structure is influenced by both melt properties and density of ore. The above results show that among the three ores, $\mathrm{C}$ results in a sinter of more favorable structure, followed by A and B.

\subsection{Prediction of Sinter Properties from Blend Compo- sition Using Fluidity Index}

Equations (2)-(13) show that $R, T$ and $t$ are the main factors affecting the fluidity index $(F)$. Supposing reference values of $F_{i}(R), F_{i}(T)$ and $F_{i}(t)$ for ore $i$ are $F_{i}\left(R_{0}\right)$, $F_{i}\left(T_{0}\right)$ and $F_{i}\left(t_{0}\right)$ and the F-R, F-T and F-t correlations are

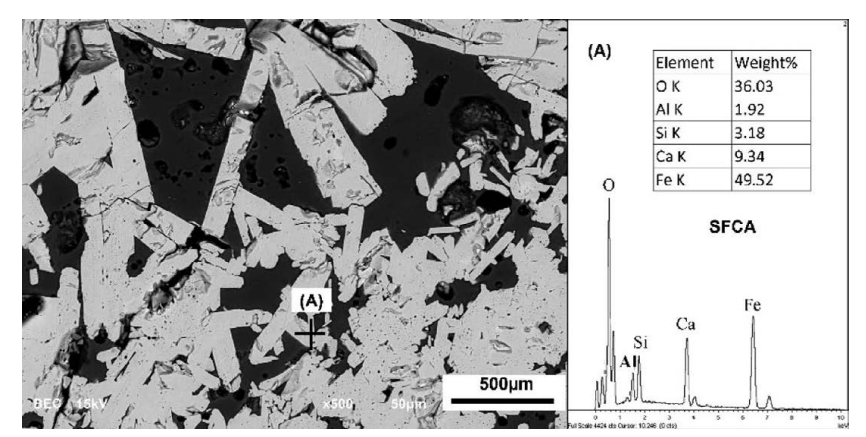

Fig. 15. SFCA (Silicoferrite of Calcium and Aluminum) at the interface sinter of blended ore. independent from one another, any variation in one of these parameters would change $\mathrm{F}$ by $\Delta F_{i}$, which can be calculated as following.

$$
\begin{aligned}
\Delta F_{i}(R) & =F_{i}(R)-F_{i}\left(R_{0}\right) . \\
\Delta F_{i}(T) & =F_{i}(T)-F_{i}\left(T_{0}\right) . \\
\Delta F_{i}(t) & =F_{i}(t)-F_{i}\left(t_{0}\right) \ldots
\end{aligned}
$$

Taking $\bar{F}_{i}\left(R_{0}, T_{0}, t_{0}\right)$ as a common point and reference value of $F_{i}(T), F_{i}(R)$ and $F_{i}(t)$, the fluidity index corresponding to different conditions of $\mathrm{R}, \mathrm{T}, \mathrm{t}$ varying can be estimated by adding the $\Delta F_{i}(R), \Delta F_{i}(T), \Delta F_{i}(t)$ to the reference value point as:

$$
F_{i}(R, T, t)=\bar{F}_{i}\left(R_{0}, T_{0}, t_{0}\right)+\Delta F_{i}(R)+\Delta F_{i}(T)+\Delta F_{i}(t) \ldots
$$

The following reference values were selected for the four ores: $R_{0}=2.6, T_{0}=1260^{\circ} \mathrm{C}$ and $t_{0}=2.0 \mathrm{~min}$. In order to validate Eq. (17), four ores were grinded to $-0.125 \mathrm{~mm}$, pressed to cake with $R=2.0$ and sintered at $T=1300^{\circ} \mathrm{C}$ for $t=1.0 \mathrm{~min}$. Figure 16(a) compares the measured and calculated $\mathrm{F}$ values for these conditions, demonstrating good agreement.

Figure 1 showed that the basicity of one ore is uneven for different particle size fractions, i.e. the ore is an inhomogeneous mixture. In order to calculate fluidity index of such mixture, we assume that the ore constitutes $n$ size fractions with mass of fraction $j$ being $\alpha_{j}$, and its basicity being $R_{j}$.
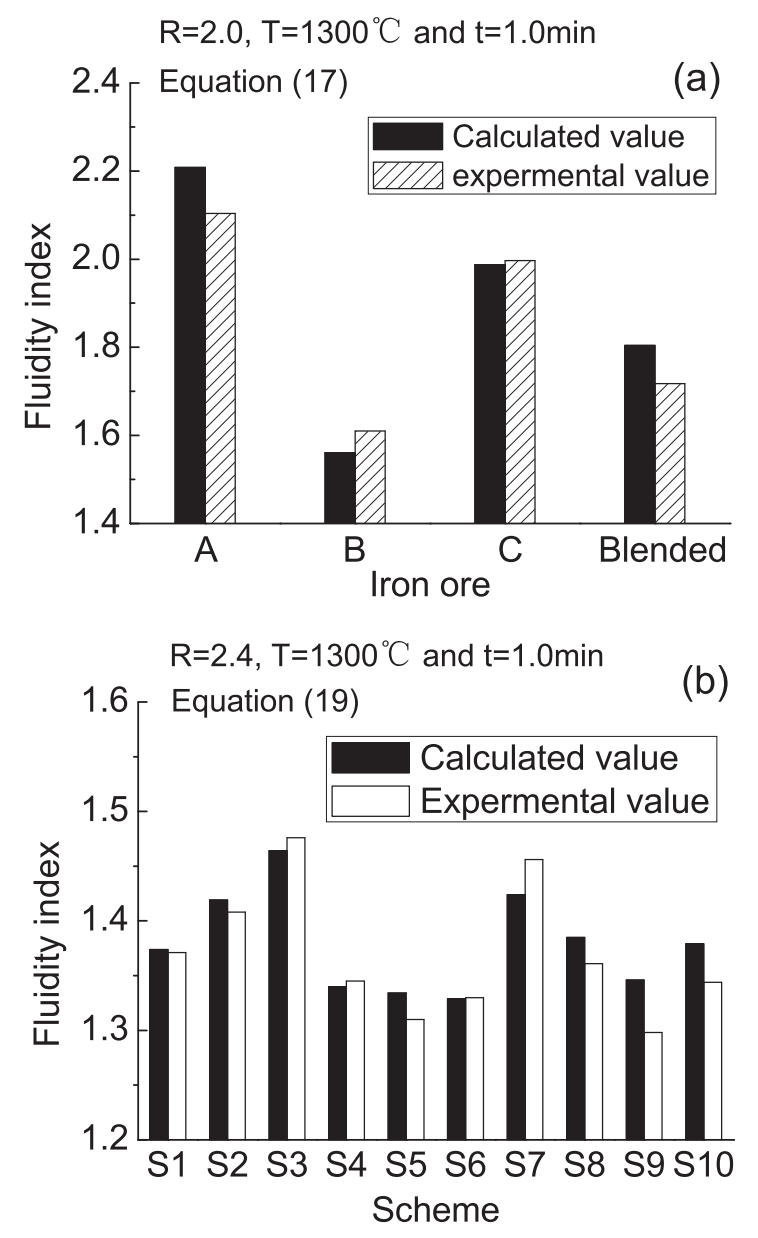

Fig. 16. Comparison of calculated and measured fluidity for various sintering conditions. 
The fluidity index of the ore, $F^{*}$ is the weighted average of fluidity index for different size fractions, i.e.:

$$
F^{*}=\sum_{j=1}^{n} \alpha_{j} F_{j}\left(R_{j}, T, t\right)
$$

This correlation assumes that the interactions between the different size fractions is negligible compared to the effects $R, T$ and $t$. If a blended ore is made by mixing $n$ different ores with mass of ore $i$ being $\gamma_{i}$ and its composite fluidity index being $F_{i}^{*}$, the fluidity index of the blend under similar conditions of $T$ and $t$ can be calculated as following.

$$
F=\sum_{i=1}^{n} \gamma_{i} F_{i}^{*}
$$

In order to validate Eq. (19), the 10 mixtures of Table 5 were grinded to size of $-0.125 \mathrm{~mm}\left(\alpha_{-0.125 \mathrm{~mm}}=100 \mathrm{wt} \%\right)$, pressed to cakes with $R=2.4$ and sintered at $T=1300^{\circ} \mathrm{C}$ for $t=1.0 \mathrm{~min}$. The comparison between calculated and measured values in Fig. 16(b) again shows a very good agreement.

In order to explore a correlation between fluidity index and sinter properties, the final feeds in Table 5 were sintered

\begin{tabular}{|c|c|c|c|c|c|c|c|c|c|c|}
\hline \multirow{4}{*}{ Tests } & \multirow{4}{*}{$F$} & \multicolumn{4}{|c|}{ Sinter properties } & \multicolumn{5}{|c|}{ Sinter reducibility } \\
\hline & & \multirow{2}{*}{ ISO TI } & \multirow{2}{*}{$\begin{array}{c}\text { Coke } \\
\text { consumption }\end{array}$} & \multirow{2}{*}{$\mathrm{FeO}$} & \multirow{3}{*}{$\mathrm{CaO} / \mathrm{SiO}_{2}$} & \multirow{2}{*}{ RDI } & \multirow{2}{*}{ RI } & \multicolumn{3}{|c|}{ Softening properties } \\
\hline & & & & & & & & $\mathrm{T} 10 \%$ & $\mathrm{~T} 40 \%$ & $\Delta \mathrm{T}$ \\
\hline & & $+6.3 \mathrm{~mm} \%$ & $\mathrm{Kg} / \mathrm{t}$ & wt. $\%$ & & $-3.15 \mathrm{~mm} \%$ & $\%$ & ${ }^{\circ} \mathrm{C}$ & ${ }^{\circ} \mathrm{C}$ & ${ }^{\circ} \mathrm{C}$ \\
\hline S1 & 0.993 & 63.87 & 58.68 & 7.33 & 1.77 & 36.2 & 87.25 & 1189 & 1353 & 164 \\
\hline $\mathrm{S} 2$ & 1.033 & 66.47 & 57.67 & 7.65 & 1.82 & 32.9 & 86.31 & 1197 & 1348 & 151 \\
\hline $\mathrm{S} 3$ & 1.073 & 65.58 & 56.14 & 7.99 & 1.81 & 33.7 & 86.22 & 1177 & 1338 & 161 \\
\hline S4 & 0.955 & 64.38 & 63.73 & 6.97 & 1.80 & 37.9 & 88.51 & 1161 & 1349 & 188 \\
\hline S5 & 0.974 & 65.21 & 59.86 & 7.29 & 1.81 & 40.3 & 89.53 & 1175 & 1348 & 173 \\
\hline S6 & 0.988 & 63.48 & 58.33 & 7.46 & 1.71 & 38.5 & 88.38 & 1181 & 1347 & 166 \\
\hline S7 & 1.034 & 68.53 & 57.16 & 8.26 & 1.79 & 33.4 & 84.73 & 1193 & 1350 & 157 \\
\hline S8 & 0.995 & 70.80 & 59.58 & 8.02 & 1.80 & 29.7 & 82.16 & 1182 & 1334 & 152 \\
\hline S9 & 0.955 & 67.94 & 62.85 & 7.70 & 1.83 & 23.6 & 84.46 & 1179 & 1319 & 140 \\
\hline S10 & 0.994 & 66.41 & 58.49 & 7.82 & 1.78 & 34.8 & 85.63 & 1186 & 1347 & 161 \\
\hline S & 0.980 & 66.17 & 58.76 & 7.73 & 1.76 & 32.2 & 83.14 & 1192 & 1349 & 157 \\
\hline Average & & 66.24 & 59.20 & 7.66 & 1.79 & 33.9 & 86.03 & 1183 & 1344 & 161 \\
\hline
\end{tabular}

Table 6. Sinter properties, reducibility and calculated fluidity index for different sinter feeds.
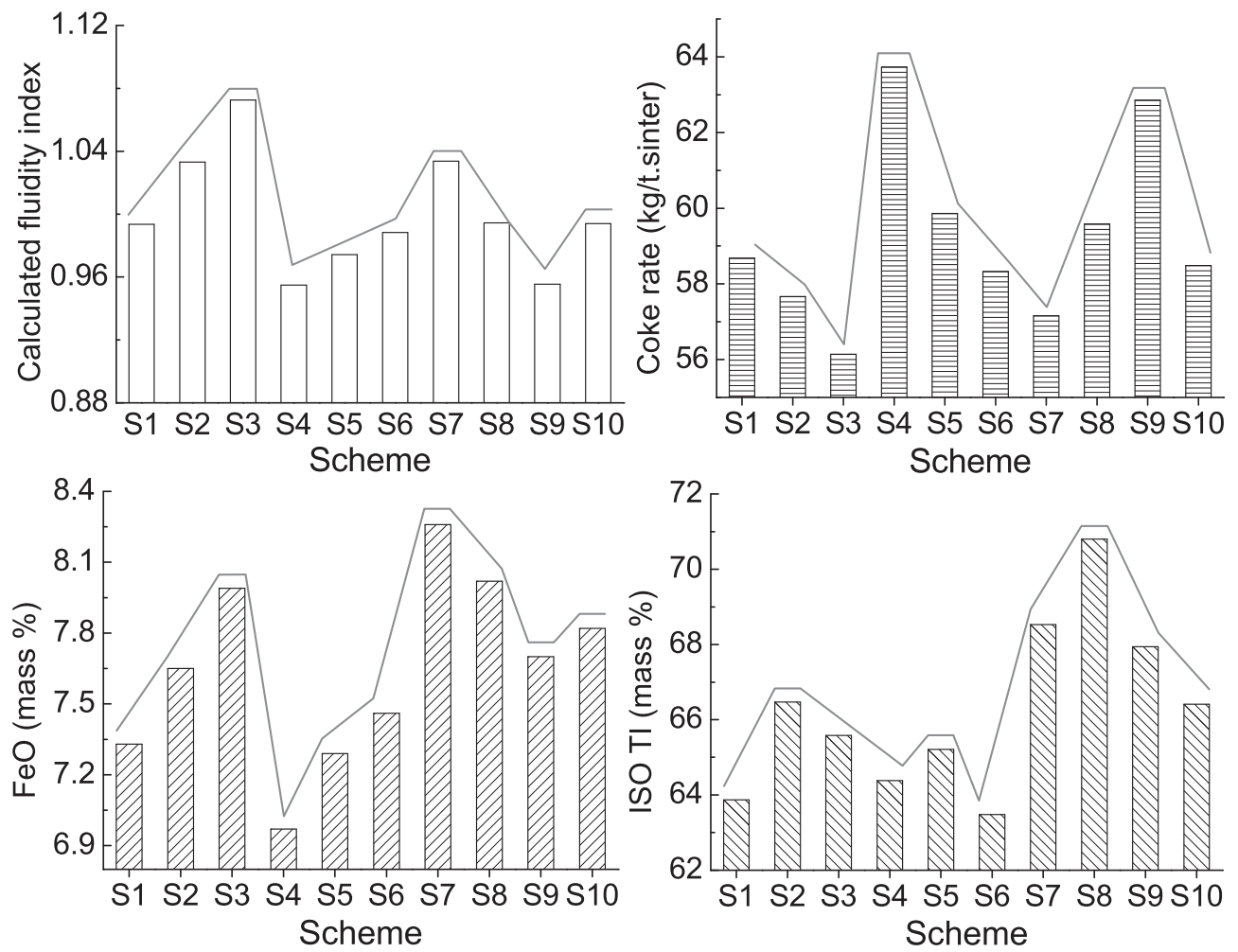

Fig. 17. Trends of the calculated fluidity index and the experimental sinter properties. 
in a sinter pot and their properties were measured (Table 6). In addition, from the basicity ratio of different size fractions in Fig. 1, size distribution of the ores (Table2) and method described above, the fluidity index of S1-10 was calculated and the results are provided in Table 5 .

Different groups of mixtures were prepared and tested for the following purposes. Sinters S3, S6 and S9 were made to study the effect of adding different low-grade ores to the base ore, therefore their amount was fixed at $15 \mathrm{wt} \%$. The ISO TI $(+6.3 \mathrm{~mm})$ of three sinters are $65.6 \%, 63.5 \%$, $67.9 \%$, and the RDIs $(+6.3 \mathrm{~mm})$ are $33.7 \%, 38.5 \%, 23.6 \%$, respectively. These trends are fully consistent with the effect of three ores on sinter structure, Fig. 14.

Mixtures S7, S8 and S9 reveal the effect of $\mathrm{A}+\mathrm{C}$ on sinter properties, with increasing the rate of ore $\mathrm{C}$ and decreasing ore A the fluidity is more favorable to promote the sinter strength, so their ISO TI exceed the average value of $66.2 \%$ by $2.3 \%, 4.6 \%, 1.7 \%$, respectively. The RDIs are below the average value of $33.9 \%$ by $0.5 \%, 4.2 \%$, and $10.3 \%$, respectively.

The effects of adding $\mathrm{A}+\mathrm{B}$, and $\mathrm{B}+\mathrm{C}$ were studied through (S1, S2, S3) and (S4, S5, S6) groups, respectively. Figure 17 presents the properties and calculated fluidity index of all sinters for comparing the trends. It is evident that some properties of sinter such as coke consumption and FeO content are related to the $F$. For example, the calculated $F$ of S1, S2 and S3, which test the influence of increasing ore A and decreasing ore B, are 0.993, 1.033, and 1.073. They follow the same order as $\mathrm{FeO}$ content $(7.3 \%, 7.7 \%$, $8.0 \%$ ) and an inverse trend with the coke consumption $(58.7 \%, 57.7 \%, 56.2 \%)$.

The trends of ISO TI and fluidity index are not strongly consistent, likely due to the different densities of ore A, B and C. Nevertheless, it is clear that the way important sinter properties change with varying the blend composition can be predicted using the methods discussed here.

\section{Conclusions}

The effect of addition of coarse-grain, low-grade iron ores to a base ore on the melt formation and sinter structure properties was studied. Correlations were established between melt fluidity and sintering conditions. The following conclusions were drawn.

(1) The quantity and fluidity of liquid phase in sinter is significantly increased by $\mathrm{SiO}_{2}$ addition. $\mathrm{Al}_{2} \mathrm{O}_{3}$ has a small positive effect on these and $\mathrm{MgO}$ suppresses them slightly.

(2) The formation of liquid phase and its interactions with solids are mainly influence by the gangue content of ore as well as basicity, temperature and soaking time. For ores with good assimilation and high melt fluidity, the small pores merge to form large ones.

(3) The bonding and pore structure of sinter are primarily determined by melt behavior and are also effected by the density (pore structure) of coarse ore. Proper melt can decrease the pores and improve the bonding in sinter. Coarser particles with low density favor development of a melt-infiltrated layer on particles.

(4) Empirical correlations can be established to calculate melt fluidity from the ore composition and sintering regime. Such correlations are effective for predicting the behavior of various ore mixtures in sintering.

\section{REFERENCES}

1) X. Lv, C. Bai, Q. Deng, X. Huang and G. Qiu: ISIJ Int., 51 (2011), 722.

2) C. Kamijo, M. Matsumura and T. Kawaguchi: ISIJ Int., 45 (2005), 544.

3) S. Yoshimura, K. Kurosawa, Y. Gonda, S. Sukenaga, N. Saito and K. Nakashima: ISIJ Int., 49 (2009), 687.

4) D. Oliveira, S. Wu, Y. Dai, J. Xu and H. Chen: J. Iron Steel Res. Int., 19 (2012), 1

5) N. Oyama, H. Sato, K. Takeda, T. Ariyama, S. Masumoto, T. Jinno and N. Fujii: ISIJ Int., 45 (2005), 817.

6) J.-W. Jeon, S.-W. Kim and S.-M. Jung: ISIJ Int., 55 (2015), 513.

7) M. Hara, T. Kawaguchi, M. Matsumura and C. Kamijo: ISIJ Int., 49 (2009), 609.

8) M. Gan, X. Fan, Z. Ji, X. Chen, L. Yin, T. Jiang, G. Li and Z. Yu: ISIJ Int., 55 (2015), 742

9) Z. Yu, G. Li, T. Jiang, Y. Zhang, F. Zhou and Z. Peng: ISIJ Int., 55 (2015), 907.

10) Y. Iwami, T. Yamamoto, T. Higuchi, N. Oyama, M. Sato and Y. Sodani: ISIJ Int., 55 (2015), 2350.

11) T. Umadevi, A. Brahmacharyulu, P. Karthik, P. C. Mahapatra, M. Prabhu and M. Ranjan: Ironmaking Steelmaking, 39 (2012), 222.

12) W. Yu, T. Sun, Z. Liu, J. Kou and C. Xu: ISIJ Int., 54 (2014), 56.

13) K. Nakashima, N. Saito, S. Shinozaki, R. Tanaka, T. Maeda, M. Shimizu and K. Mori: ISIJ Int., 44 (2004), 2052.

14) A. Cores, A. Babich, M. Muniz, S. Ferreira and J. Mochon: ISIJ Int., 50 (2010), 1089

15) X. Lv, C. Bai, Q. Deng, X. Huang and G. Qiu: ISIJ Int., 51 (2011), 722.

16) M. Nakano and J. Okazaki: ISIJ Int., 51 (2011), 1418.

17) R. Bergstrand, J. Khosa, A. Waters and J. Garden: ISIJ Int., 45 (2005), 492.

18) S. Bu-xin, Z. Jian-liang, W. Da, S. Jiu-gang, R. Shan and W. Guang-wei: J. Iron Steel Res. Int., 21 (2013), 8.

19) L. Hong-ge, Z. Jian-liang, P. Yuan-dong, Z. Zhi-xing and M. Ze-jun: J. Iron Steel Res. Int., 18 (2011), 11.

$20)$ S. Machida, K. Nushiro, K. Ichikawa, H. Noda and H. Sakai: ISIJ Int., 45 (2005), 513.

21) A. Cores, A. Babich, M. Muniz, S. Ferreira and J. Mochon: ISIJ Int., 50 (2010), 1089

22) T. Otomo, Y. Takasaki and T. Kawaguchi: ISIJ Int., 45 (2005), 532.

23) N. Hayashi, S. V. Komarov and E. Kasai: ISIJ Int., 49 (2009), 681.

24) S. Machida, T. Higuchi, N. Oyama, H. Sato, K. Takeda, K. Yamashita and K. Tamura: ISIJ Int., 49 (2009), 667.

25) F. Kongoli and A. Yazawa: Metall. Mater. Trans. B, 32 (2001), 583.

26) H. Kimura, T. Ogawa, M. Kakiki, A. Matsumoto and F. Tsukihashi: ISIJ Int., 45 (2005), 506. 